\title{
Peran Public Relations (Hubungan Masyarakat) Dalam Meningkatkan Reputasi MAN 1 Banyuwangi
}

\author{
Moh. Harun Al Rosid ${ }^{1}$, M. Syahrul Munir ${ }^{2}$ \\ e-mail : harun2939@gmail.com ${ }^{1}$, syahrulmunir123@gmail.com \\ Prodi Manajemen Pendidikan Islam \\ Institut Agama Islam Darussalam Blokagung Banyuwangi
}

\begin{abstract}
The objectives of this study are: (1) to determine the role of public relations in improving the reputation of MAN 1 Banyuwangi and (2) to determine the supporting and inhibiting factors of public relations in improving the reputation of MAN 1 Banyuwangi. This research method uses descriptive qualitative, with data collection techniques through interviews, observation and documentation. Data analysis used interactive 3 models of Miles \& Hurberman (1) data reduction, (2) data presentation and (3) conclusion and verification, while the data validity technique used triangulation. The results show that the reputation of MAN 1 Banyuwangi in 2019 has increased. This was realized because the Public Relations staff had worked hard and worked together from all components of the school, such as teachers, employees, and students with stakeholders. The role of Public Relations Staff in improving the reputation of MAN 1 Banyuwangi in 2019 is as follows: (1) Collaborating with community leaders, (2) Conducting harmonious reciprocal relationships with the surrounding community and student guardians, (3) Developing positive opinions of MAN 1 Banyuwangi in the eyes of the community and student guardians, (5) Conducting promotions through brochures, oral and student achievements, (6) Consultation with internal stakeholders regarding policies.
\end{abstract}

Keywords: Role of Public Relations, Reputation.

\begin{abstract}
Abstrak
Tujuan penelitian ini adalah: (1) untuk mengetahui peran public relations dalam meningkatkan reputasi MAN 1 Banyuwangi dan (2) untuk mengetahui faktor pendukung dan penghambat public relations dalam meningkatkan reputasi MAN 1 Banyuwangi. Metode penelitian ini menggunakan deskriptif kualitatif, dengan teknik pengumpulan data melalui wawancara, observasi dan dokumentasi. Analisis data menggunakan interaktif 3 model Miles \& Hurberman (1) reduksi data, (2) penyajian data dan (3) penarikan kesimpulan dan verifikasi, sedangkan teknik keabsahan data menggunakan triangulasi. Hasil penelitian menunjukan bahwa Reputasi MAN 1 Banyuwangi tahun 2019 mengalami peningkatan. Hal tersebut terwujud karena Staff Public Relations telah bekerja keras dan kerja sama dari semua komponen sekolah, seperti guru, karyawan, serta siswa dengan stakeholder. Peran Staff Public Relations dalam meningkatkan reputasi MAN 1 Banyuwangi tahun 2019 adalah berikut ini: (1) Melakukan kerja sama dengan tokoh masyarakat, (2) Melakukan hubungan timbal balik yang harmonis dengan masyarakat sekitar dan wali murid, (3) Mengembangkan opini positif MAN 1 Banyuwangi di mata masyarakat dan wali murid, (5) Melakukan promosi baik melalui brosur, lisan maupun prestasi siswa, (6) Konsultasi dengan Stakeholder intern terkait kebijakan.
\end{abstract}

Kata kunci : Peran Public Relations, Reputasi. 


\section{A. Pendahuluan}

1. Latar Belakang

Aset berharga bagi kemajuan bangsa Indonesia adalah pendidikan. Karena dengan pendidikan, dapat mencetak generasi muda yang berkarakter dan berkompeten dalam membangun bangsa ini. Generasi muda yang berkarakter dan berkualitas dapat terlahir dari lembaga pendidikan Islam yang memiliki tujuan, visi dan misi pendidikan yang searah dengan tujuan bangsa indonesia, “...mencerdaskan kehidupan bangsa" seperti yang termasuk dalam pembukaan Undang-Undang Dasar (UUD) 1945 alinea ke IV. Lembaga pendidikan Islam yang berkualitas merupakan sebuah instansi pendidikan yang memiliki citra positif di mata masyarakat sekitarnya dimana lembaga tersebut berada. Nama lain dari citra positif adalah reputasi. Reputasi adalah harta berharga yang wajib dimiliki setiap lembaga sebagai bukti eksistensi dan kualitas lembaga. Reputasi Madrasah menunjukan kualitas pendidikan dalam madrasah atau sekolah tersebut.

Public relations memiliki fungsi dan peran dalam mengelola reputasi serta harus bisa memberikan ide yang cemerlang untuk meningkatkan reputasi mendatang. Strategi yang sesuai dan berfaedah merupakan sarana untuk mendapatkan reputasi yang diinginkan. Mukarom dan Laksana (2016:450) memaparkan bahwa, "Public relations adalah seni menciptakan pengertian publik yang lebih baik sehingga dapat memperdalam kepercayaan publik terhadap lembaga/organisasi”. Organisasi dalam hal ini diartikan sebagai lembaga pendidikan Islam.sedangkan publik dalam hal ini dalam hal ini meliputi masyarakat sekitar, tokoh masyarakat dan wali siswa. Public relations memahami persepsi yang dipegang oleh lembaga pendidikan Islam dan memberi informasi mengenai kinerja suatu lembaga kepada semua masyarakat yang bersangkutan. Public relations bertugas mengembangkan reputasi yang pantas untuk sebuah organisasi, yang didasarkan pada kinerja. Reputasi merupakan penilaian yang tidak harus baik, tetapi hanya nilai yang pantas diperoleh lembaga tersebut. Reputasi 
atau citra positif sebuah lembaga pendidikan Islam merupakan hasil kerja nyata Public relations lembaga tersebut, misalnya lembaga pendidikan Islam MAN 1 Banyuwangi.

Aspek reputasi merupakan hal utama dalam mendapatkan kepercayaan masyarakat (orang tua calon siswa) untuk memilih Madrasah yang dituju. Reputasi Madrasah di mata masyarakat sangat perlu dibangun karena sekolah tidak akan bisa berjalan tanpa adanya dukungan dari masyarakat. Contohnya adalah begitu banyaknya lembaga pendidikan Islam MA/SMA di Banyuwangi sehingga menuntut MAN 1 Banyuwangi harus tetap eksis dan mempunyai reputasi yang baik dalam persaingan tersebut. Kepercayaan masyarakat terhadap keberadaan MAN 1 Banyuwangi yang sangat besar harus tetap dipertahankan. Peran Staff Public Relation dalam membina komunikasi dengan masyarakat harus terus dimaksimalkan. Bisa jadi, kurangnya komunikasi dan kerjasama internal public dan eksternal public dapat menghambat staff public relations sekolah dalam membangun reputasi sekolah. Akibatnya, sekolah tidak dapat berkembang dengan baik dan tidak bisa jadi tidak mendapatkan siswa sesuai yang diinginkan target.

MAN 1 Banyuwangi merupakan lembaga pendidikan Islam berbasis Islami yang menempati lokasi di Jalan ikan Tengiri No.2 Sobo, Banyuwangi. Prestasi dan reputasi madrasah yang memiliki visi “ Unggul Dalam Ilmu Pengetahuan dan Teknologi yang Dilandasi Iman dan Taqwa serta Berwawasan Lingkungan" harus dipertahankan. Pada tahun pembelajaran 2018/2019 MAN 1 Banyuwangi mempunyai siswa sebanyak 1272. Hal ini sebagai wujud kepercayaan dari masyarakat yang sangat tinggi. Oleh sebab itu, setiap komponen dalam Madrasah harus menyadari perannya sebagai representasi dari Madrasahnya sehingga masyarakat dapat memberi penilaian yang positif. Dalam kata lain bahwa setiap khalayak internal adalah menjadi Public relations bagi intitusinya.

Upaya untuk meningkatkan reputasi Madrasah membutuhkan kerja keras dan kebersamaan warga MAN 1 Banyuwangi, serta dukungan dari 
semua pihak. Peran Public Relation sangat berpengaruh dalam membangun reputasi serta Stakeholder yang mempunyai komitmen untuk memajukan lembaga Madrasah MAN 1 Banyuwangi. MAN 1 Banyuwangi merupakan salah satu Madrasah favorit di kota Banyuwangi. Dalam data referensi Kementerian Pendidikan dan Kebudayaan (KEMENDIKBUD) jumlah Madrasah Menengah Atas di Kecamatan Banyuwangi menunjukkan Sembilan (9) lembaga pendidikan Islam dan hanya ada satu lembaga yang berada di bawah naungan Kementerian Agama yang berbentuk Madrasah yakni, Madrasah Aliyah Negeri Banyuwangi.

Peran Public relations MAN 1 Banyuwangi sangat berpengaruh dalam membangun reputasi positif di mata masyarakat. Dimana masyarakat dengan suka rela berperan aktif dalam mewujudkan tujuan, visi, dan misi madrasah MAN 1 Banyuwangi. Berdasarkan pengamatan peneliti di lapangan, ditemukan data bahwa jumlah pendaftar peserta didik baru di MAN 1 Banyuwangi mengalami peningkatan dua kali lipat dari tahun sebelumnya. Tetapi jumlah tersebut masih kalah jika dibandingkan dengan sekolah negeri yang telah berdiri jauh sebelum MAN 1 banyuwangi misalnya saja SMA N Giri, Akan tetapi, MAN 1 Banyuwangi masih mampu bersaing dengan sekolah negeri lainnya dalam segi jumlah prestasi akademik maupun non akademik.

2. Rumusan Masalah

1) Bagaimana peran public relations dalam meningkatkan reputasi MAN 1 Banyuwangi?

2) Apa faktor pendukung dan penghambat public relations dalam meningkatkan reputasi MAN 1 Banyuwangi?

3. Tujuan Penelitian

1) Untuk mengetahui peran public relations dalam meningkatkan reputasi MAN 1 Banyuwangi.

2) Untuk mengetahui faktor pendukung dan penghambat public relations dalam meningkatkan reputasi MAN 1 Banyuwangi. 
4. Manfaat

Adapun Manfaat penelitian ini adalah :

a. Manfaat Teoritis

1) Penelitian ini dapat memberikan sumbangan pemikiran bagi tentang peran Public relations di Lembaga pendidikan Islam (madrasah).

2) Bagi pelaksana Public relations, penelitian ini dapat memberikan sumbangan maupun referensi untuk melaksanakan tugasnya.

b. Manfaat Praktis

1. Manfaat bagi MAN 1 Banyuwangi, penelitian ini dapat dijadikan referensi untuk memperbaiki kelemahan ataupun kekurangan Wakamad Humas (public relations) menyusun kebijakan yang lebih baik dalam meningkatkan reputasi MAN 1 Banyuwangi.

2. Bagi peneliti, penelitian ini dapat menambah pengetahuan dan wawasan mengenai Public relations, serta untuk memperoleh pengalaman dalam menganalisis peran Public relations dalam upaya meningkatkan reputasi MAN 1 Banyuwangi

3. Bagi pembaca, penelitian ini dapat memberikan informasi secara tertulis maupun sebagi referensi mengenai Public relations dan peran Public relations MAN 1 Banyuwangi.

\section{B. Landasan Teori}

\section{Definisi Public Relations}

Public Relations merupakan nama lain dari Hubungan Masyarakat (Humas). Harlow dalam Rusady (2016 :16), mendefiniskan "Public relations adalah fungsi manajemen yang khas dan mendukung pembinaan, pemeliharaan jalur bersama antara rganisasi dengan publiknya, menyangkut aktivitas komunikasi, pengertian, penerimaan dan kerja sama, melibatkan manajemen dalam menghadapi permasalahan, mendukung manajemen dalam menghadapi permasalahan, membantu manajemen dalam menghadapi opini publik, mendukung manajemen dalam mengikuti dan memanfaatkan perubahan secara 
efektif, bertindak sebagai sistem peringatan dini dalam mengantisipasi kecenderungan penggunaan penelitian serta teknik komunikasi yang sehat dan etis sebagai sarana utama".

Rachmadi dalam Mukarom dan Laksana (2015:56) mengungkapkan bahwa, "fungsi utama public relations adalah menumbuhkan dan mengembangkan hubungan baik antara lembaga dengan publiknya (internal maupun eksternal) dalam rangka menanamkan pengertian, menumbuhkan motivasi, dan partisipasi publik dalam upaya menciptakan iklim pendapat (opini publik) yang menguntungkan lembaga tersebut. Mukarom dan Laksana (2015:46) menyatakan bahwa, "aktivitas Public relations sehari-hari adalah menyelenggarakan komunikasi timbal balik (two way traffic communication) antara lembaga dan pihak publik yang bertujuan menciptakan saling pengertian dan dukungan bagi tercapainya tujuan tertentu, kebijakan, kegiatan produksi, demi kemajuan lembaga atau citra positif lembaga bersangkutan". Lembaga dalam hal ini adalah lembaga pendidikan Islam. Sedangkan pihak publiknya adalah masyarakat.

Public relations adalah suatu proses memprediksi setiap kemungkinan dan konsekuensi dari setiap kegiatannya serta melaksanakan program-program yang telah direncanakan untuk mencapai tujuan lembaga pendidikan Islam. Definisi tersebut mengandung aspek yang cukup penting dalam public relations yaitu teknik komunikasi yang sehat dan etis. Bidang public relations harus memiliki karakter unggul baik dari segi perilaku dan cara bertutur kata. Perkataan yang lembut, sopan dan santun menjadi senjata yang ampuh untuk menarik perhatian publik. Sasaran Public relations adalah public, yaitu sekelompok orang yang memiliki suatu kepentingan yang sama, tujuan yang sama dan membutuhkan penyelesaian. external public adalah sekelompok orang yag berada di luar lembaga pendidikan Islam yang mempunyai kepentingan dengan lembaga pendidikan Islam tersebut, meliputi masyarakat (wali siswa), komite madrasah, dan stakeholder.

Peran Public Relations (Hubungan Masyarakat) Dalam Meningkatkan Reputasi Man 1 Banyuwangi

Moh. Harun Al Rosid, M. Syahrul Munir 
Public relations memiliki posisi yang sangat penting dalam sebuah lembaga pendidikan Islam. Apalagi, lembaga pendidikan Islam merupakan lembaga yang sangat membutuhkan interaksi dengan masyarakat. Public relations merupakan bagian dari staff lembaga pendidikan Islam yang melakukan hubungan langsung dengan masyarakat, menyalurkan informasi tentang kebijakan-kebijakan lembaga pendidikan Islam kepada masyarakat, menciptakan hubungan baik yang berkesinambungan dengan masyarakat. Karena itu kesan positif lembaga pendidikan Islam di mata masyarakat sangat ditentukan oleh staff public relations yang dalam hal ini di sebut wakil Kepala Madrasah bidang hubungan masyarakat.

\section{Fungsi Public relations}

Bernay dalam Rosady Ruslan (2016:18) memaparkan tentang 3 fungsi utama Public relations, yaitu:

a. Memberikan penerangan kepada masyarakat.

Staff public relations menjadi media komunikasi antara lembaga pendidikan Islam dengan masyarakat. Dimana kebijakankebijakan lembaga pendidikan Islam diterangkan dengan jelas, sehingga menumbuhkan saling pengertian dan saling kepercayaan.

b. Melakukan persuasi untuk mengubah sikap dan perbuatan masyarakat secara langsung.

Berarti Staff public relations melakukan aksi pendekatan secara langsung kepada masyarakat. Pendekatan yang sangat efektif dan efisien adalah pendekatan dari hati ke hati. Karena dengan pendekatan ini, perbuatan masyarakat yang awalnya kontra dengan kebijakan lembaga pendidikan Islam, bisa berubah menjadi tindakan berupa dukungan masyarakat. Bahkan masyarakat bisa ikut andil berkerja sama misalnya, dalam pelaksanaan program-program lembaga pendidikan Islam. 
c. Berupaya untuk mengintegrasikan sikap dan perbuatan suatu badan/lembaga sesuai dengan dengan sikap dan perbuatan masyarakat atau sebaliknya.

Staff public relations berupaya mengorganisasikan kegiatan yang berlangsung di lembaga pendidikan Islam sesuai dengan kebiasaan dan adat istiadat yang berlaku di masyarakat. Sehingga dapat dinerima dengan mudah oleh masyarakat.

\section{Tujuan Public Relations}

Frida Kusumastuti dalam Mukarom dan Laksana (2016:55) menjelaskan bahwa, "Tujuan public relations adalah memelihara dan membentuk rasa saling pengertian, menjaga dan membentuk rasa saling percaya, serta memelihara dan menciptakan kerjasama yang baik". Ditinjau dari kepentingan lembaga pendidikan Islam, pengembangan penyelenggaran hubungan lembaga pendidikan Islam dengan masyarakat bertujuan untuk:

a. Memelihara kelangsungan hidup lembaga pendidikan Islam.

b. Meningkatkan mutu pendidikan pada lembaga yang bersangkutan.

c. Memperlancar proses belajar mengajar.

d. Memperoleh dukungan dan bantuan dari masyarakat yang diperlukan dalam pengembangan dan pelaksanaan program Madrasah.

Sedangkan jika ditinjau dari kebutuhan masyarakat itu sendiri, tujuan hubungannya dengan lembaga pendidikan Islam adalah sebagai berikut:

a. Meningkatkan kesejahteraan masyarakat. Terutama meningkatkan kesehatan mental-spiritual. Sebab, pembelajaran yang berlangsung dalam lembaga pendidikan Islam meliputi pendidikan keberanian, kemandirian, dan keagamaan.

b. Memperoleh bantuan Madrasah dalam mencari solusi dari permasalahan yang dihadapi masyarakat. Misalnya, masalah masyarakat yang berkaitan dengan kenakalan anaknya (siswa).

Peran Public Relations (Hubungan Masyarakat) Dalam Meningkatkan Reputasi Man 1 Banyuwangi

Moh. Harun Al Rosid, M. Syahrul Munir 
c. Menentukan jaminan keterkaitan program Madrasah dengan kebutuhan masyarakat.

d. Mencetak kader-kader masyarakat yang berkompeten dalam menciptakan kemajuan di lingkungan masyarakat.

Rahmat Abdul (2016:119) berpendapat bahwa, "Hubungan sekolah dengan masyarakat merupakan jalinan interaksi yang diupayakan oleh sekolah agar dapat diterima di tengah-tengah masyarakat untuk mendapatkan aspirasi, dan simpati dari masyarakat, serta mengupayakan terjadinya kerjasama yang baik antar sekolah dengan masyarakat untuk kebaikan bersama, atau secara khusus bagi sekolah penjalinan hubungan tersebut adalah untuk mensuksekan program-program sekolah yang bersangkutan sehingga sekolah tersebut bisa tetap eksis.”

Keberadaan hubungan antara masyarakat dengan lembaga pendidikan Islam akan menciptakan rasa saling percaya dan saling pengertian sehingga terbentuk kerja sama yang antara masyarakat dengan lembaga pendidikan Islam. Keuntungan yang lain, hubungan harmonis akan mempermudah pencegahan maupun penyelesaian dari masalah yang dihadapi oleh kedua belah pihak. Berdasarkan uraian di atas, dapat disimpulkan bahwa tujuan diadakannya hubungan Madrasah dengan masyarakat adalah:

a. Mencegah kesalahpahaman antara kedua belah pihak.

b. Menciptakan kerja sama yang harmonis dan menguntungkan kedua belah pihak.

c. Memperoleh bantuan materiil, dan finansial serta moral guna memperlancar kegiatan pembangunan lembaga pendidikan Islam.

d. Merumuskan kebijakan bersama demi kemajuan lembaga pendidikan Islam.

4. Reputasi

Reputasi adalah penilaian baik atau buruk yang berkembang dari waktu ke waktu. Reputasi dalam lembaga pendidikan Islam sangat 
berkaitan dengan finansial, emosi, sosial, dan kultural antara lembaga pendidikan Islam dengan masyarakat, baik masyarakat internal maupun eksternal. Lembaga pendidikan Islam memiliki reputasi baik ketika mereka dipandang menguntungkan bagi masyarakat. Reputasi yang diperoleh berawal dari opini Publik. Opini publik merupakan persepsi masyarakat tentang lembaga pendidkan tersebut yang berakar dari faktor latar belakang Madrasah, isu-isu, nilai-nilai yang dianut, serta beritaberita yang berkembang di masyarakat. Persepsi yang dipengaruhi oleh beberapa faktor tersebut, kemudian akan membentuk opini publik baik opini yang bersifat mendukung ataupun opini yang bersifat menentang atau berlawanan. Inilah kegiatan inti yang harus dilakukan staff public relations. Kualitas kinerja staff public relations menentukan reputasi lembaga pendidikan Islam.

Opini publik yang bersifat dukungan terhadap lembaga pendidikan Islam, kemudian dari waktu ke waktu akan berkembang menjadi citra positif. Citra positif merupakan tujuan utama atau prestasi yang hendak dicapai oleh staff public relations. Citra Positif disebut juga sebagai reputasi lembaga pendidikan Islam. Citra positif adalah kesan baik, gambaran, perasaan dukungan masyarakat terhadap lembaga pendidikan Islam dan sengaja ditumbuhkan oleh staff public relations. Soemirat dan Ardianto (2017:113) mengemukakan bahwa, “citra adalah cara bagaimana pihak lain memandang sebuah perusahaan seseorang, suatu komite atau suatu aktivitas". Apabila dikaitkan dengan institusi pendidikan, berarti citra tidak lepas dari persepsi, pandangan, dan penilaian masyarakat terhadap lembaga pendidikan Islam.

Menurut Soemirat dan Ardianto (2016 : 115) Model pembentukan citra dalam struktur kognitif dapat dijelaskan melalui bagan berikut: 
Gambar 2.1

Model pembentukan citra dalam struktur kognitif

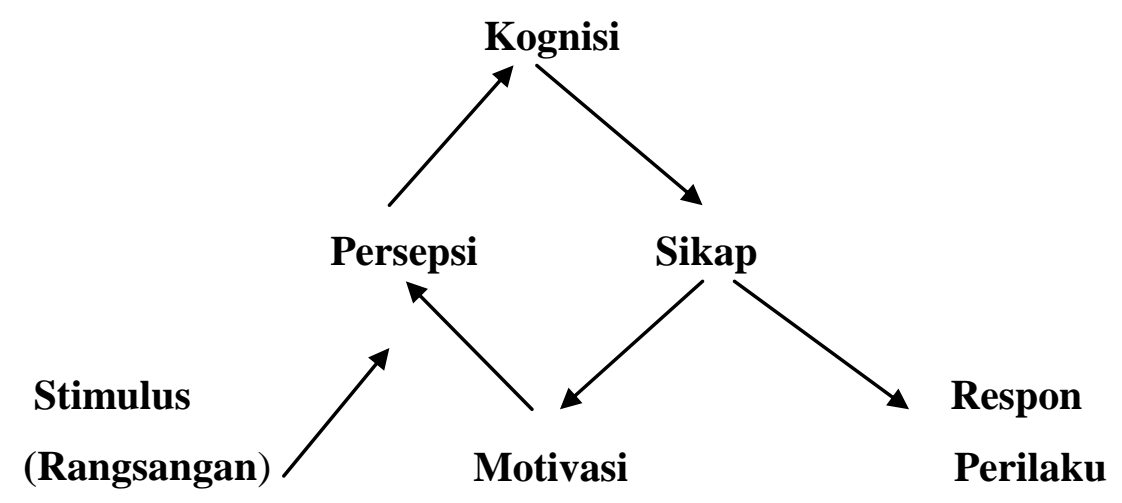

Sumber : Soemirat dan Ardianto (2016: 115)

Keterangan :

1. Persepsi adalah pemahaman makna masyarakat tentang rangsangan yang diberikan oleh staff public relations. Masyarakat cenderung memberikan makna sesuai dengan pengalamannya mengenai rangsangan. Persepsi disebut juga sebagai pendangan masyarakat. Pendangan ini akan bernilai positif apabila informasi yang disebarkan (rangsangan) dapat memenuhi kognisi masyarakat.

2. Kognisi adalah keyakinan diri masyarakat terhadap rangsangan. Untuk menumbuhkan keyakinan masyarakat, staff public relations harus memberikan informasi yang lengkap dan menarik minat masyarakat. Karena keyakinan ini akan tumbuh setelah masyarakat mampu memahami rangsangan yang telah diberikan.

3. Motivasi adalah keadaan dalam pribadi masyarakat yang mampu mendorong mereka untuk melakukan kegiatan dengan penuh semangat untuk mencapai tujuan tertentu.

4. Sikap adalah kecenderungan untuk berperilaku dengan cara-cara tertentu. Sikap sangat dipengaruhi oleh motivasi. Sikap 
menentukan apakah masyarakat akan mendukung atau menolak rangsangan yang diberikan oleh Staff public relations.

5. Sikap dan motivasi yang terwujud akan menggerakkan masyarakat untuk memberikan respon sesuai dengan yang diinginkan staff public relations. Respon perilaku masyarkat yang bersifat pro diharapkan bisa memberikan keuntungan bagi lembaga pendidikan Islam baik dukungan moral, finansial maupun material.

Hasil dari Proses Pembentukan citra adalah pendapat atau tanggapan masyarakat, sikap dan respon perilaku. Tujuan utama membangun citra positif adalah untuk mendapatkan pengakuan dari masyarakat, dan selanjutnya masyarakat bersedia membantu masalahmasalah yang dihadapi lembaga pendidikan Islam. Citra positif yang telah dicapai dalam kurun waktu tertentu akan berkembang menjadi reputasi. Dalam Kamus Besar bahasa Indonesia citra adalah "rupa/gambar", gambaran yang dimiliki orang banyak mengenai pribadi, perusahaan, organisasi atau produk. Sedangkan reputasi berasal dari kata "nomina" (kata benda) perbuatan dan sebagainya sebagai sebab mendapat nama baik. Citra dan Reputasi memiliki artian yang serupa yakni sama-sama bentuk penggambaran nama baik dari sebuah lembaga/organisasi tertentu.

\section{Kajian Terdahulu}

1. Penelitian Kurnia, Santoso dan Rahmanto yang berjudul "Strategi Public Relations Dalam Meningkatkan Reputasi Madrasah (Studi Kasus di SMA Negeri 1 Surakarta)", pada tahun 2013. Jenis penelitian deskriptif kualitatif dengan metode studi kasus. Hasil penelitian tersebut, menyatakan bahwa reputasi Madrasah telah sesuai dengan visi Madrasah. Namun, masih terdapat dinamika yang mempengaruhi reputasi Madrasah. Citra positif Madrasah belum terbangun dengan maksimal. Peran public relations Madrasah tersebut hanya mampu memberikan rasa kepercayaan 
stakeholder saja. Penelitian ini tidak menjelaskan secara rinci bagaimanakah reputasi atau citra positif Madrasah tersebut di kalangan khalayak masyarakat, hanya dipaparkan dengan pernyataan umum bahwa rasa percaya Stakeholder menunjukkan bahwa reputasi Madrasah berada pada level memuaskan.

2. Penelitian serupa juga pernah diteliti dalam judul "Manfaat Public relations dalam Membangun Reputasi Madrasah (Pemahaman Fungsi Public relations di SMA 1 Tanjung Pandan Belitung)", dengan peneliti Setyanto dan Winduwati pada tahun 2016 dengan jenis penelitian Penelitian deskriptif kualitatif. Hasil penelitian tersebut menyatakan bahwa Reputasi wajib dibangun bagi semua organisasi, tak terkecuali Madrasah. Dalam membangun reputasi dalam penelitian ini hanya terfokus pada pemberian pemahaman khalayak internal seperti, guru, siswa-siswi, dan karyawan Madrasah. Padahal reputasi atau citra positif itu juga sangat membutuhkan opini masyarakat.

Berdasarkan Ilustrasi tersebut, peneliti menemukan perbedaan antara Penelitian pertama dengan penelitian kedua. Yaitu terletak pada fokus Penelitiannya, Subjek Penelitian, Dan Hasil Penelitian. Penelitian pertama yang berjudul Strategi Public Relations Dalam Meningkatkan Reputasi Madrasah (Studi Kasus Di SMA Negeri 1 Surakarta), membahas tentang strategi yang telah dilakukan oleh staff Public relations SMA Negeri 1 Surakarta dalam membangun reputasi Sekolah. Langkah-langkah yang telah dilakukan oleh Public relations. Hasilnya, upaya yang telah dilakukan oleh Staff Public relations hanya mampu memuaskan hasrat stakehoder saja, dalam artian belum maksimal. Reputasi di masyarakat tidak diteliti lebih mendalam, sehingga tidak tau secara pasti apakah reputasi sekolah tersebut di mata masyarakat.

Sedangkan penelitian kedua, yang berjudul "Manfaat Public relations dalam Membangun Reputasi Madrasah (Pemahaman Fungsi Public relations di SMA 1 Tanjung Pandan Belitung)", terfokus pada cara untuk memberikan pemahaman kepada Publik Internal (Guru, Karyawan 
madrasah, siswa) tentang manfaat staff Public relations dalam membangun reputasi sekolah. Kelemahan penelitian ini, hanya terfokus pada public internal saja. Padahal, unsur masyarakat juga sangat penting dalam proses pembangunan ataupun peningkatan reputasi madrasah.

Sedangkan rencana penelitian ini, fokus terhadap usaha Madrasah melalui bidang hubungan masyarakat (public relations) dalam meningkatkan reputasi madrasah tersebut. Mengingat madrasah tidak bisa terpisah dari stakeholder dan masyarakat. Dimana peran stakeholder dan masyarakat sangat berpengaruh dalam meningkatkan kualitas dan prestasi MAN 1 Banyuwangi yang selanjutnya berdampak pada reputasi MAN 1 Banyuwangi. Peneliti merasa perlu untuk melakukan penelitian secara mendalam tentang peran public relations serta dukungan stakeholder dan masyarakat dalam meningkatkan reputasi madrasah.

\section{Metode Penelitian}

Penelitian ini menggunakan jenis penelitian deskriptif kualitatif yakni penelitian yang bersifat mendeskripsikan hasil penelitian sebagai jawaban dari rumusan masalah penelitian. Pada penelitian ini peneliti mengkonsentrasikan pada peran public relation dalam meningkatkan reputasi di MAN 1 Banyuwangi. Lokasi penelitian ini ialah Madrasah Aliyah Negeri 1 Banyuwangi. Sumber data yang digunakan dalam penelitian ini ada dua yaitu: sumber data primer dan sekunder. Sumber data primer adalah sumber data yang dipakai oleh peneliti dalam menghimpun data utama yakni pengelola MAN 1 Banyuwangi sebagai nara sumber utama dan observasi langsung di lembaga untuk mendapatkan data berupa kondisi nyata masalah penelitian . Sedangkan sumber data sekunder didapat dari bagian tata usaha untuk mendapatkan data terkait administrasi dan data pendukung penelitian lainnya. Dalam penelitian ini teknik pengumpulan data menggunakan observasi, wawancara, dan dokumentasi. Analisis data dalam penelitian ini menggunakan 
analisis interaktif 3 model Miles \& Huberman meliputi: (1) Reduksi data, (2) penyajian data dan (3) pengambilan keputusan.

\section{E. Hasil Penelitian}

Hasil penelitian yang diperoleh dari wawancara dengan beberapa informan berikut ini:
a. Stakeholder Internal, yaitu Kepala Madrasah dan Staff Public Relations.
b. Stakeholder Eksternal, yaitu tokoh masyarakat sekitar.
c. Wali Murid.
d. Masyarakat sekitar.

1. Data Tentang peran Public relations MAN 1 Banyuwangi tahun 2019.

Kutipan wawancara dengan Kepala Madrasah Drs. H. Saeroji, M.Pd.I, sebagai berikut :

"Staff Public Relations di sekolah ini menjalankan tugasnya dengan sangat baik. MAN 1 Banyuwangi bisa mendapatkan kepercayaan dari masyarakat itu, salah satunya hasil kerja keras mereka. Mereka sering mengadakan kegiatan yang melibatkan masyarakat sekitar, misalnya Diesnatalis MAN. Iya yang paling terlihat itu, tahun ini jumlah pendaftar calon peserta didik baru semakin banyak dari pada tahun sebelumnya".

\section{Gambar 4.2}

Wawancara dengan Kepala MAN 1 Banyuwangi.

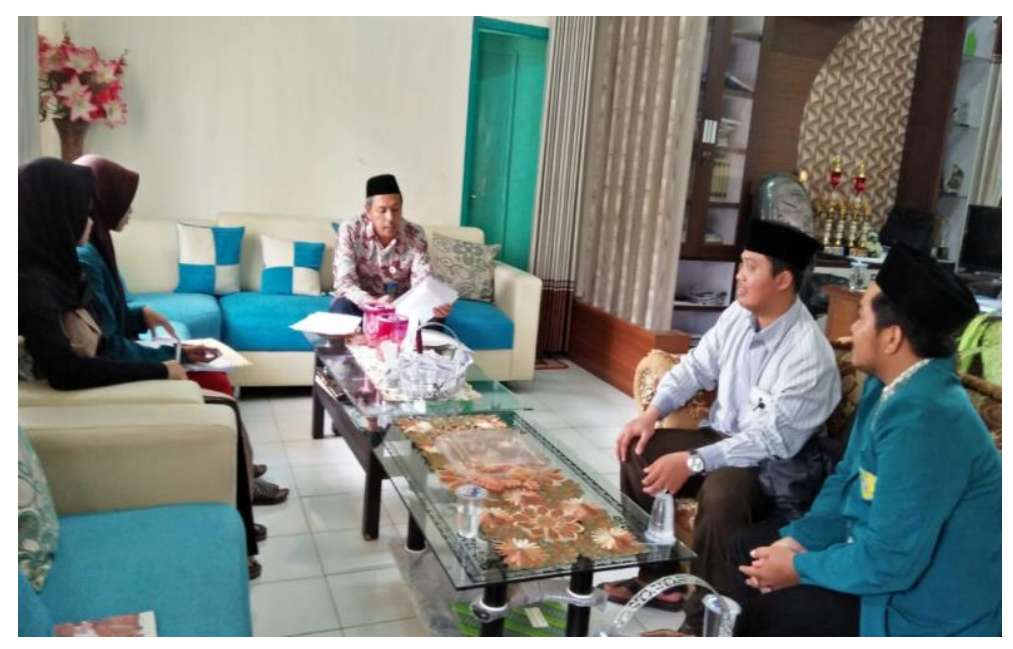

Peran Public Relations (Hubungan Masyarakat) Dalam Meningkatkan Reputasi Man 1 Banyuwangi

Moh. Harun Al Rosid, M. Syahrul Munir 
Sumber : Dokumentasi Peneliti, 2019

Kutipan wawancara dengan Staff Public Relations, sebagai berikut :

"Selama ini tim menyusun strategi yang dapat diterima oleh masyarakat. mengenalkan prestasi dan kekreatifan peserta didik kami. Harapan kami MAN 1 Banyuwangi tetap menjadi sekolah favorit yang akan dipilih pertama kali oleh calon siswa baru. Alhamdulilah, prestasi akademik maupun non akademik siswa MAN 1 Banyuwangi meningkat. Selain itu, kabar baik dengan diterimanya sebagian siswa di melalui jalur SNMPTN DAN SPAN PTKIN bisa kami jadikan data terampuh untuk melakukan promosi kepada masyarakat".

Kutipan wawancara dengan Tokoh Masyarakat (RT), sebagai berikut :

"Mereka (Staff Public relations) sering konsultasi terlebih dahulu ketika akan diadakan acara di MAN. Seringnya mereka menanyakan terkait keamanan, konfirmasi masalah siswa seperti, siswa bobol sekolah, siswa melakukan pertengkaran pelajar. Itu mereka nanya nya ke saya. Sampai saat ini aman-aman saja. Tidak ada siswa MAN yang melakukan kenakalan tersebut. Mereka sering pesan ke saya jika ada kegiatan masyarakat sekitar desa ini, minta dikabari. Siapa tau siswa MAN bisa ikut memeriahkan".

Tidak jauh berbeda dengan pendapat di atas, ketua Rukun Warga pun menyampaikan, sebagai berikut :

"pihak Public Relations telah melakukan banyak koordinasi untuk masalah perizinan setiap acara yang diadakan didalam area kampus MAN 1 Banyuwangi”.

Kutipan wawancara dengan Kepala Madrasah, sebagai berikut :

"Staff public relations MAN 1 Banyuwangi selalu menawarkan ide-ide promosi maupun kebijakan baru yang bisa membuat MAN bnyuwangi semakin dikenal masyarakat luas. Selain mengikuti lomba akademik maupun non akademik, mereka juga memasang Baliho di tempat strategis di sekitar masyarakat. Selain itu, mereka berkoordinasi dengan guru BK menyelesaikan permasalahan siswa di MAN. Menyediakan stan khusus brosur MAN 1 Banyuwangi dan menggratiska siapaun yang mengambilnya. Hingga saat ini, mereka mampu meningkatkan

Peran Public Relations (Hubungan Masyarakat) Dalam Meningkatkan Reputasi Man 1 Banyuwangi

Moh. Harun Al Rosid, M. Syahrul Munir 
reputasi MAN 1 Banyuwangi. Jumlah pendaftar calon peserta didik baru tahun 2019 lebih banyak dari tahun sebelumnya."

Kutipan wawancara dengan Stakeholder Ekstern (Rukun Tetangga), sebagai berikut:

" yang saya tahu, jumlah pendaftar di MAN 1 Banyuwangi selalu meningkat. Ya semua itu karna staff Public Relations selalu bekerja keras. Mereka itu setiap ada acara selalu totalitas, disiplin. Kayak pas buat brosur itu, pasti tiap tahun sekali pas ada diesnatalis, mereka menyediakan stan khusus buat brosur gratis. Isinya ya tentang MAN 1 Banyuwangi. Alhamdulilahnya, karna itu semua MAN 1 Banyuwangi ini selalu kebanjiran pendaftar calon peserta didik baru. Ini ya, tahun ini yang daftar aja sekitar 6-enam ratusan lebih".

Berdasarkan kutipan wawancara tersebut menunjukkan bahwa Staff Public relations sangat berperan aktif dalam meningkatkan reputasi MAN 1 Banyuwangi tahun 2019. Mereka menyusun startegi, mengambil tindakan serta melakukan pendekatan dengan berbagai pihak agar rencananya dapat berjalan dengan lancar.

Berdasarkan kutipan wawancara di atas, menunjukkan bahwa peran Public

Relations MAN 1 Banyuwangi pada tahun 2019 adalah public relations mampu meningkatkan reputasi MAN 1 Bnayuwangi di mata masyarakat. hal tersebut ditunjukan dengan kepercayaan masyarakat yang semakin meningkat. Misalnya jumlah pendaftar calon peserta didik baru tahun 2019/2020 lebih banyak dari pada tahun sebelumnya.

2. Data Tentang Reputasi MAN 1 Banyuwangi

Kutipan wawancara dengan Tokoh Masyarakat (Rw), sebagai berikut:

"MAN 1 Banyuwangi itu sekolahan yang sangat bagus. Kebanyakan siswanya sopan, memiliki etika yang baik berbeda dengan pelajar pada umumnya. Apabila ada kegiatan masyarakat siswa MAN ikut andil membantu masayarakat. Misalnya dalam kegiatan jalan sehat HUT Desa, bersih-bersih desa, dan kegiatan kurban di masjid, dan lain-lain".

Peran Public Relations (Hubungan Masyarakat) Dalam Meningkatkan Reputasi Man 1 Banyuwangi

Moh. Harun Al Rosid, M. Syahrul Munir 
Kutipan wawancara dengan Masyarakat sekitar ibu sari penjual kopi di sekitar MAN 1, sebagai berikut :

"setahu saya, MAN 1 Banyuwangi itu selalu menolak murid setiap tahunnya. Banyak yang daftar disana, tapi yang diterima hanya sedikit. Tamatan MAN banyak yang diterima di perguruan tinggi Negeri. Apalagi siswanya baik-baik, sopan santun, tau etika, pintar ngaji. MAN bagus pokoknya, ilmu agamanya diperdalam, ilmu umumnya juga dapat".

Kutipan wawancara dengan Wali Murid Dedi Setiawan, sebagai berikut :

"siswa-siswi MAN banyak yang mengikuti lomba. Seringkali mereka mendapatkan juara. Salah satunya anak saya, lulusan MAN banyuwangi gampang mencari pekerjaan, bagi mereka yang kuliah, banyak juga yang dieterima di Perguruan Tinggi Negeri”.

Kutipan wawancara dengan Masayarakat sekitar Bapak Abdul, sebagai berikut :

"MAN Banyuwangi setiap tahun melakukan kegiatan Bazar Diesnatalis. MAN membuka stan kantin khusus untuk masyarakat sekitar yang mau jualan disana. Selain itu, masyarakat juga diizinkan berkunjung dan memeriahkan kegiatan tersebut. dalam kegiatan bersih desa, siswa MAN Banyuwangi banyak yang membantu membersihkan selokan, masjid dan lain-lain”.

Gambar 4.3

Wawancara dengan masyarakat sekitar

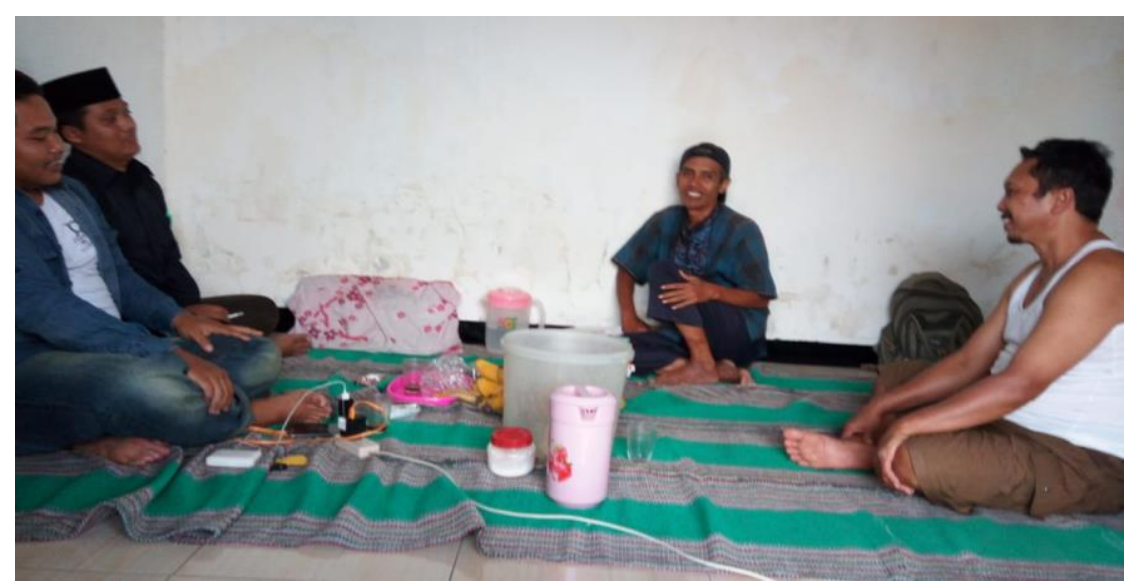

Sumber : Dokumentasi Peneliti, 2019.

Peran Public Relations (Hubungan Masyarakat) Dalam Meningkatkan Reputasi Man 1 Banyuwangi

Moh. Harun Al Rosid, M. Syahrul Munir 
Kutipan wawancara dengan Wali Murid, sebagai berikut : "saya merasa aman ketika anak saya belajar di MAN 1 Banyuwangi. Karena saya tak khawatir lagi anak saya akan salah pergaulan. Di MAN ini, dia diajari ilmu agama. Dia jadi tahu waktunya sholat, waktunya mengaji, dan beretika".

Kutipan wawancara dengan Kepala Madrasah, sebagai berikut : "kami selalu mengikuti lomba-lomba baik akademik maupun non akademik. Pernah ada yang lolos sampai tingkat kabupaten dan propinsi. Siswa kami setiap tahunnya selalu ada yang diterima di SNMPTN Undangan. Tahun 2019 ini terdapat 18 siswa diterima di PTN ternama. Sedangkan yang diterima melalui SPAN PTKIN sebanyak 36 siswa".

Berdasarkan kutipan wawancara di atas, peneliti menyimpulkan bahwa reputasi baik MAN 1 Banyuwangi tahun 2019 semakin meningkat di mata masyarakat. Tahun ini MAN 1 Banyuwangi mampu mengantarkan anak didiknya sebanyak 36 siswa diterima di Perguruan Tinggi Negeri (PTN) melalui jalur SNMPTN. Serta 36 siswa diterima di Perguruan Tinggi Negeri Berbasis Islam melalui jalur SPAN PTKIN. Selain itu, wali murid sangat yakin dan percaya bahwa anak-anaknya akan berhasil dunia dan akhirat apabila disekolahkan di kampus MAN 1 Banyuwangi.

3. Faktor-faktor apa yang mendukung dan menghambat Public relations dalam meningkatkan reputasi MAN 1 Banyuwangi

Kutipan wawancara dengan Staff Public Relations, sebagai berikut :

"Selama ini hal yang mendukung tim kami melakukan tindakan adalah izin. Jadi bapak Kepala Madrasah ini selalu tanggap dan antusias dengan strategi yang kami rencanakan. Selain itu, juga bantuan dari teman-teman guru yang ikut serta mengawasi siswa sehingga kegiatan yang kami rencanakan berjalan dengan lancar. Tokoh masyarakat dan komite sangat berpengaruh dalam menyukseskan seluruh rencana yang ami susun. Mereka sering kali merespon positif terhadap kami. Namun, beberapa kali pendanaan yang kurang membuat kami kurang maksimal dalam 
bekerja. Karena seluruh kegiatan kami memutuhkan dana yang tidak sedikit. Ya terpaksa beberapa rencana hanya menjadi sebuah wacana saja".

Kutipan wawancara di atas menunjukkan bahwa faktor yang mendungkung kelancaran public relations dalam meningkatkan reputasi MAN 1 Banyuwangi adalah perizinan, dukungan dan bantuan dari tokoh masyarakat, komite, serta seluruh guru. Sedangkan faktor yang menghambat upaya public relations dalam meningkatkan reputasi MAN 1 Banyuwangi adalah pendanaan.

\section{F. Pembahasan}

1. Peran Public Relations yang telah dilaksanakan di MAN 1 Banyuwangi.

Peran staff Public Relations di MAN 1 Banyuwangi telah berjalan sesuai dengan harapan dari Kepala Madrasah, dengan alasan dan ditunjukkan bukti bahwa setiap tahunnya MAN 1 Banyuwangi mengalami peningkatan pada jumlah pendaftar calon peserta didik baru setiap tahun ajaran baru. Pun beberapa Stakeholder Eksternal juga menyatakan bahwa Staff Public Relations yang ada di MAN 1 Banyuwangi sering berdiskusi tentang kegiatan yang ada di Madrasah tersebut. Mereka meminta pendapat terkait strateginya.

Peran staff Public Relations dalam hal peningkatan jumlah pendaftar disetiap tahunnya juga sangat dipengaruhi dengan adanya kepercayaan dari wali murid. Hal ini telah dibuktikan dengan terus bertambahnya pendaftar setiap tahun ajaran barunya dan dengan melakukan kualifikasi yang bagus bagi para pendaftarnya MAN 1 Banyuwangi mampu meningkatkan berbagai prestasi yang diperoleh oleh para siswa baik prestasi akademik maupun non akademik merupakan akan menjadikan nilai positif bagi MAN 1 Banyuwangi untuk terus menjaga Reputasi baik yang telah menjadi opini dari khalayak luas.

Mayoritas wali murid yang mendaftarkan anaknya di MAN 1 Banyuwangi sangat yakin anak-anaknya bisa menjadi orang yang sukses dan berhasil nantinya. Karena mereka memiliki prinsip hidup yang sama dengan visi misi MAN 1 Banyuwangi. Beberapa wali murid yang telah 
diwawancarai oleh peneliti, menyatakan bahwa mereka bangga sekali anaknya sekolah di MAN 1 Banyuwangi. Mereka merasakan sendiri perubahan sikap anaknya menjadi lebih baik, lebih rajin mengaji, disiplin dalam hal beribadah, dan sopan terhadap orang tua.

\section{Reputasi MAN 1 Banyuwangi}

Dalam Hal Reputasi baik semua lembaga Profit maupun Non Profit pasti membutuhkanya untuk keberlangsungan dari lembaga tersebut baik untuk meningkatkan kuantitas maupun kualitas dari yang dihasilkan olehnya. Seperti, lembaga MAN 1 Banyuwangi yang telah berhasil menumbuhkan opini baik kepada khalayak umum secara luas dan terus menjaganya melalui kerjasama disetiap pihak yang terkait dalam bidangnya.

Reputasi MAN 1 Banyuwangi terlihat nyata pada fakta-fakta yang ditemui peneliti dalam lapangan, diantaranya:

a) Jumlah pendaftar calon peserta didik baru yang semakin meningkat dari tahun ke tahun.

b) Prestasi MAN 1 Banyuwangi dalam berbagai perlombaan tingkat kecamatan, kabupaten dan provinsi, baik akademik maupun non akademik.

c) Prestasi Siswa-siswi MAN 1 Banyuwangi yang diterima di Perguruan Tinggi Negeri melalui jalur SNMPTN undangan.

d) Prestasi Siswa-siswi MAN 1 Banyuwangi yang diterima di Perguruan Tinggi Negeri melalui jalur SPAN PTKIN.

e) Lulusan MAN 1 Banyuwangi mudah dalam mencari pekerjaan.

f) Siswa-siswi MAN 1 Banyuwangi lebih unggul dalam pengetahuan agama, memiliki etika, sopan santun, dan kesadaran untuk disiplin dalam menjalankan ibadah dibandingkan dengan siswa-siswi dari sekolah lainnya. 
3. Faktor-faktor pendukung dan penghambat staff Public Relations dalam upaya meningkatkan reputasi MAN 1 Banyuwangi

Berikut ini beberapa faktor pendukung dan penghambat staff Public Relations dalam meningkatkan reputasi MAN 1 Banyuwangi:

a. Faktor pendukung yaitu perizinan, dukungan dan bantuan dari tokoh masyarakat, komite, serta seluruh guru. Mereka bersama-sama membantu baik tenaga, finansial maupun material serta turut memeriahkan setiap kegiatan yang dilaksanakan oleh staff Public Relations.

b. Faktor penghambat yaitu pendanaan. Pendanaan di lembaga terbilang kurang dari cukup untuk memfasilitasi kegiatan staff Public Relations. Sering kali pendanaan menjadi kendala terbesar rencana yang telah disusun dengan matang terpaksa gagal direalisasikan.

\section{G. Kesimpulan}

Berdasarkan hasil pembahasan dapat disimpulkan sebagai berikut:

1. Peran public relation dalam meningkatkan Reputasi MAN 1 Banyuwangi tahun 2019 sangatlah baik. Dibuktikan dengan prestasi siswa dan peningkatan jumlah pendaftar peserta didik baru setiap tahunnya. Hal tersebut dapat terwujud karena peran Staff Public Relations yang telah berjalan sesuai dengan tugas dan fungsinya. Dengan bekerja keras dan cerdas serta kerja sama dari semua komponen dalam sekolah, seperti Stakeholder, guru, karyawan, serta siswa.

2. Dalam kinerjanya staff Public Relation terdapat faktor pendukung dan penghambat sebagai berikut :

a. Faktor pendukung, berupa dukungan dan bantuan dari tokoh masyarakat, komite, serta seluruh guru. Mereka bersama-sama membantu baik tenaga, finansial maupun material serta turut memeriahkan setiap kegiatan yang dilaksanakan oleh staff Public Relations. 
b. Faktor penghambat, penghambat dalam kinerja Public Relations berupa Pendanaan. Karena pendanaan di lembaga terbilang kurang dari cukup untuk memfasilitasi kegiatan staff Public Relations. Sering kali pendanaan menjadi kendala terbesar rencana yang telah disusun dengan matang terpaksa gagal direalisasikan.

\section{H. Daftar Pustaka}

Arikunto, Suharsimi. 2014. Prosedur Penelitian Suatu Pendekatan Praktik. Jakarta: Pt Rineka Cipta.

Cutlip M.Scoot dan Center H.Allen. 2009. Effective Public relations. Jakarta : Kencana.

Data Referensi Kementerian Pendidikan dan kebudayaan. 2019. Jumlah Data Satuan Pendidikan (Sekolah) Per Kabupaten/Kota : Kab.Banyuwangi, Jakarta : Kemdikbud Senaya jakarta.

Margono S. Drs. 2007. Metologi Penelitian Pendidikan Komponen MKDK. Jakarta : PT.Rineka Cipta.

Mukarom, zainal dan laksana, muhibudin wijaya. 2015. Manajemen Public relations(panduan efektif pengelolaan hubungan). Surakarta : Pustaka setia.

Ruslan, Rosady. 2016. Manajemen Public relations \& Media Komunikasi. Jakarta: PT. Raja Grafindo Persada.

Peraturan Kementerian Pendidikan dan Kebudayaan No.17 Tahun 2017 tentang Jumlah Peserta Didik dalam satu rombongan Belajar. 2018. iGenst.id.

Rahmat, Abdul. 2016. Manajemen Humas Sekolah. Yogyakarta : Media Akademi.

Riduwan. 2004. Metode Riset. Jakarta : Rineka Cipta.

Sidqi, Taufik. 2016. Kekurangan Murid, Tiga Sekolah di Ponorogo akan Ditutup. DetikNews.

Sugiyono. 2017. Metode Penelitian Pendidikan (Pendekatan Kuantitatif, Kualitatif, dan R\&D. Bandung : Alfabeta. 